\title{
Os Riscos do Agrotóxico Glifosato: Controvérsia Científica ou Negação do Dano À Saúde Humana?
}

\author{
Risks of the Herbicide Glyphosate: Scientific \\ Controversy or Denial of Human Health Damages?
}

\section{Los Riesgos del Plaguicida Glifosato: iControversia Científica o Negación de Daño para a la Salud HUMANA?}

\author{
Jeferson Jeldoci Pol* \\ Haide Maria Hupffer ${ }^{* *}$ \\ João Alcione Sganderla Figueiredo ${ }^{* * *}$
}

\begin{abstract}
1 Introdução. 2 A necessária autoconfrontação com os riscos da tecnociência pela lente do sociólogo Ulrich Beck. $3 \mathrm{O}$ olhar da ciência sobre o agrotóxico glifosato. 4 A controvérsia científica entre os organismos internacionais e de agências reguladoras sobre o glifosato. 5 Decisões do sistema jurídico dos Estados Unidos e do Brasil frente aos riscos do agrotóxico à saúde humana. 6 Conclusão. Referências.
\end{abstract}

* Doutorando em Qualidade Ambiental na Universidade Feevale. Mestre em Qualidade Ambiental pela Universidade Feevale. Graduado em Direito. Integrante do Projeto de Pesquisa Agrotóxicos e Sociedade de Risco: limites e responsabilidade pelo risco ambiental. Advogado na área ambiental e trabalhista. Vice-Presidente da Comissão Especial de Direito Ambiental da OAB/NH e Membro da Associação Gaúcha dos Advogados de Direito Ambiental Empresarial - AGAAE. Novo Hamburgo, RS, BR. E-mail: <jefersonpoladv@gmail.com>. http://orcid.org/0000-0001-9131-1012

** Pós-doutora em Direito pela Unisinos. Doutora em Direito e Mestre em Direito pela Unisinos. Especialista em Recursos Humanos e Graduada em Direito pela Unisinos. Graduada em Ciências Contábeis pela Fundação Machado de Assis agregada a PUCRS. Professora e pesquisadora no Programa de Pós-Graduação em Qualidade Ambiental e no Curso de Graduação em Direito da Universidade Feevale. Novo Hamburgo, RS, BR. E-mail: <haide@feevale.br>. http://orcid.org/00000002-4965-9258

*** Possui graduação em Filosofia pela Faculdade de Filosofia Nossa Senhora da Imaculada Conceição (1999), Mestrado em Ciências Sociais (PUC -RS) e Doutorado em Sociologia - Universidad Complutense de Madrid (2008). Atualmente é Pró-reitor de Pesquisa, Pós-graduação e Extensão e professor pesquisador da Universidade Feevale no Programa de Doutorado e Mestrado em Qualidade Ambiental e Mestrado em Administração. Novo Hamburgo, RS, BR. E-mail: <sganfigue@feevale.br>.http://orcid.org/0000-0003-3012-0794 


\section{RESUMO}

Objetivo: $\mathrm{O}$ artigo objetiva examinar a controvérsia científica em relação ao agrotóxico glifosato, o qual, durante muitos anos, foi considerado seguro para a saúde humana e sustentável ambientalmente, mas que, na atualidade, está sendo questionado pelo sistema da ciência e pelo sistema do direito em relação aos riscos e ao dano futuro.

Metodologia: A metodologia utilizada é a sistêmico-construtivista, a partir das contribuições de Niklas Luhmann, que possibilita examinar como cada sistema percebe o agrotóxico glifosato. No que tange às técnicas de procedimento, utiliza-se a revisão sistemática da literatura, pesquisa bibliográfica, documental e jurisprudencial.

Resultados: Conclui-se que o sistema da ciência, ao comprovar correlação entre o glifosato e os danos à saúde humana, levou a sociedade a movimentos que vão desde a proibição do agrotóxico em alguns países até indenizações bilionárias às vítimas impetradas pelo sistema jurídico. Entretanto, o caminho é longo para que o agrotóxico mais consumido no mundo seja efetivamente banido.

Contribuições: Ao examinar dados do sistema da ciência (pesquisas científicas), do sistema político (agências nacionais e internacionais de regulação) e do sistema do direito (ações e decisões na esfera judicial), o estudo oferece uma reflexão sobre o processo de autoconfrontação da sociedade com os riscos que ela própria criou ao lançar produtos, como o glifosato, sem pesquisas suficientes para indicar sua utilização segura.

Palavras-chave: Agrotóxicos. Dano Futuro. Glifosato. Modernização Reflexiva. Risco à saúde.

\section{ABSTRACT}

Objective: This article aims to examine the scientific controversy regarding the pesticide glyphosate, which for many years was considered safe for human health and environmentally sustainable, but which is currently being questioned by science and by the law systems in relation to risks and future damage.

Methodology: The methodology used is systemic-constructivist, based on the contributions of Niklas Luhmann, which allows to examine how each system perceives the pesticide glyphosate. Regarding procedural techniques, systematic literature review, bibliographic, documentary and jurisprudential research were performed.

Results: The science system, by proving a correlation between glyphosate and human health damages, led society to movements ranging from the ban on pesticides in some countries to to billionaire compensation to victims brought by the legal system. However, there is a long way for the effective banishment of the most consumed pesticide in the world.

Contributions: This study examined data from the science system (scientific research), the political system (national and international regulatory agencies) and the legal system (actions and decisions in the judicial sphere). In doing so, it offers a reflection on the 
process of self-confrontation of the society with the risks it created when launching products, such as glyphosate, without sufficient research to indicate its safe use.

Keywords: Pesticides. Future Damages. Glyphosate. Reflective Modernization. Health Risks.

\section{RESUMEN}

Objetivo: El artículo tiene como objetivo examinar la controversia científica sobre el plaguicida glifosato, que durante muchos años se consideró seguro para la salud humana y ambientalmente sostenible, pero que actualmente está siendo cuestionado por el sistema de la ciencia e por el derecho en relación a riesgos y prejuicios futuros.

Metodología: La metodología utilizada es sistémica-constructivista, basada en los aportes de Niklas Luhmann, lo que permite examinar cómo cada sistema percibe el plaguicida glifosato. En cuanto a las técnicas procedimentales, se utiliza la revisión sistemática de la literatura, investigación bibliográfica, documental y jurisprudencial.

Resultados: Se concluye que el sistema de la ciencia, al demonstrar correlación entre el glifosato y daño para la salud humana, llevó a la sociedad a movimientos que van desde la prohibición del plaguicida en algunos países hasta indemnizaciones billonarias a las victimas interpuestas por el sistema judicial. Sin embargo, el camino es largo para que el plaguicida más consumido en el mundo sea efectivamente prohibido.

Aportes: Al examinar dados del sistema científico (investigaciones científicas) del sistema político (organismos reguladores nacionales e internacionales) e del sistema jurídicos (acciones y decisiones en el ámbito judicial), el estudio ofrece una reflexión sobre el proceso de autoconfrontación de la sociedad con los riesgos que ella propria creó al lanzar productos como el glifosato, sin las suficientes instigaciones para indicar su uso seguro.

Palabras clave: Plaguicida. Daño Futuro. Glifosato. Modernización Reflexiva. Riesgo para la Salud.

\section{INTRODUÇÃO}

O modelo tecnológico empregado na agricultura no Pós-Segunda Guerra Mundial decorre da decisão de muitos países, em especial, dos Estados Unidos, de utilizarem laboratórios de empresas químicas e de empresas bélicas para o desenvolvimento de inseticidas sintéticos com a justificativa de ampliar a produção de alimentos. Para atender à demanda de alimentos no Pós-Guerra, uma das formas seria a criação de agentes letais com enorme potencial biológico para combater insetos e ervas daninhas que assolavam as plantações agrícolas. Nas décadas seguintes, a indústria química continuou a lançar inúmeras substâncias tóxicas no mercado, sem estudos sobre suas consequências a longo prazo ao meio ambiente e à saúde humana. $\mathrm{Na}$ 
atualidade, o modelo agrícola alicerçado no aumento de produção de alimentos com utilização de produtos químicos para controlar os organismos que afetam a produção, tornou-se dependente dessa tecnologia. Em paralelo, cresce a preocupação em relação à saúde humana e ao meio ambiente com pesquisas científicas que associam o desenvolvimento de inúmeras doenças com a utilização massiva do agrotóxico glifosato na produção agrícola.

O agrotóxico à base de glifosato é o mais utilizado na agricultura brasileira e também está presente em 119 países com diferentes marcas (MORAES; ROSSI, 2010, p. 23). Enquanto países, como o Brasil e Estados Unidos, utilizam em larga escala o Glifosato, em outros países, como na Áustria, Suécia, Vietnam, Bermudas, Malawi, Togo, Vietña, Sri Lanka, Omã, Arabia Saudita, Kuwait, Emirados Árabes, Catar e Bahrain, sua venda é proibida por ser considerado prejudicial à saúde humana (GREGORI, 2021), como já aconteceu com o pesticida DDT e gases como HCFC. No sistema político, sistema econômico, sistema da ciência e nas agências reguladoras, percebe-se uma controvérsia científica sobre riscos futuros e doenças associadas à exposição ao glifosato. Por outro lado, demandas judiciais, associando o uso do glifosato ao desenvolvimento de câncer, chegam ao sistema jurídico que decide pela suspensão de seu uso ou condena empresas à indenização milionárias. Somente nos Estados Unidos tramitam mais de 95 mil processos relacionados ao agrotóxico.

Diante desse tema, o presente artigo pretende responder aos seguintes questionamentos: Há evidências científicas que comprovam riscos de agrotóxicos à base do glifosato e seus sais para a saúde humana? Como a controvérsia científica está chegando às agências nacionais e internacionais regulatórias e ao sistema jurídico?

O presente estudo apresenta como tema central o agrotóxico glifosato, que, durante muitos anos, foi considerado seguro para a saúde humana e sustentável ambientalmente, mas que, na atualidade, está sendo questionado pelo sistema da ciência e pelo sistema do direito em relação aos riscos à saúde humana e ao dano ambiental futuro, questionamentos que levaram Estados a proibirem o seu uso e a comercialização, tendo como alicerce a controvérsia científica sobre os riscos socioambientais, com foco principal, nos riscos à saúde humana.

A metodologia utilizada é a sistêmico-construtivista, a partir das contribuições de Niklas Luhmann ${ }^{1}$, que possibilita a observação do Sistema da Ciência, da Política e do

\footnotetext{
${ }^{1}$ A perspectiva sistêmico-construtivista oferecida por Niklas Luhmann contribui para realizar a presente reflexão pela perspectiva de considerar a realidade como uma construção de um observador. Os aportes do método sistêmico-construtivista, para observar a controvérsia científica em torno dos riscos do agrotóxico glifosato à saúde, possibilitam compreender a complexidade das múltiplas dinâmicas comunicativas diferenciadas em um ambiente complexo, por estar alicerçado no pressuposto de que "la función de la metodología no consiste unicamente en asegurar una descripción correta (no errónea) de la realidad. Más bien se trata de formas refinadas de producción y tratamiento de la inforación internas al sistema. Esto quiere decir los métodos permiten a la ivestigación científica 270 - R. Opin. Jur., Fortaleza, ano 19, n. 32, p.267-295, set./dez. 2021
} 
Direito, para examinar como cada sistema percebe o agrotóxico glifosato. Como técnica de pesquisa, utiliza-se a revisão sistemática da literatura que auxilia a estruturar as evidências disponíveis sobre os riscos já mapeados pelo Sistema ${ }^{2}$ da Ciência, pesquisa bibliográfica, documental e jurisprudencial. O presente estudo é dividido em quatro partes: i] a necessária autoconfrontação com os riscos da tecnociência pela lente do sociólogo Ulrich Beck; ii] a contextualização da controvérsia científica sobre o agrotóxico glifosato com discussão sobre os resultados das pesquisas científicas sobre os riscos para a saúde humana; iii] o olhar de organismos internacionais e agências reguladoras sobre o glifosato; iv] as decisões do Sistema Jurídico em relação a demandas judiciais sobre os riscos do agrotóxico glifosato à saúde humana.

\section{A NECESSÁRIA AUTOCONFRONTAÇÃO COM OS RISCOS DA TECNOCIÊNCIA PELA LENTE DO SOCIÓLOGO ULRICH BECK}

O autor Ulrich Beck é um sociólogo alemão que desenvolveu a Teoria da Sociedade de Risco ao propor um diagnóstico sociológico dos riscos nos anos oitenta do século XX. Em suas discussões, analisa os riscos produzidos pela sociedade industrial e a rapidez com que as inovações tecnológicas são lançadas no mercado sem a análise dos efeitos colaterais e os riscos para as presentes e futuras gerações. Os novos riscos tecnológicos são complexos e estão impactando o meio ambiente e a saúde humana, o que passa a exigir o aprofundamento de temas, como incerteza científica, dano futuro, impossibilidade de prever externamente os perigos, confrontação da sociedade consigo mesma em relação aos riscos criados, incertezas não quantificáveis, riscos invisíveis, indivisíveis, globais e transgeracionais que impactam a vida de todos os seres vivos, visto que têm potencial para se transformaram em realidade.

Os riscos da tecnociência inquietam a humanidade pela invisibilidade, imperceptibilidade, globalidade e consequências ao meio ambiente e à saúde das gerações presentes e futuras, uma vez que não "estão vinculados ao lugar em que foram gerados, a fábrica, e ameaçam a vida no planeta, sob todas as formas" (BECK, 1994, p.

sorprenderse a si misma. Pa eso se vuelve imprescindeble interrumpir el consumo imediato de realidad y conocimiento del cual proviene la sociedad" (LUHMANN, 2007, p. 22).

2 A escolha epistemológica de trabalhar a partir dos diferentes sistemas está alicerçada na Teoria dos Sistemas de Luhmann (2007) e da diferenciação que o sociólogo faz entre sistema e entorno. Um sistema é um conjunto de elementos relacionados em função de certas operações, por sua vez, o entorno é tudo aquilo que não pertence a esta rede de operações. Os sistemas em Luhmann (2007, p. 509-510) se diferenciam funcionalmente, ou seja, cada sistema cria uma racionalidade própria, o que dá identidade ao sistema e o que torna possível sua operação frente à complexidade da sociedade. Luhmann (2007, p. 509) observa que os tempos envolvidos no acoplamento estrutural entre os diversos sistemas têm ritmos diferentes, o que pode causar irritações e perturbações, citando como exemplo o sistema jurídico, ao dizer que, se o sistema jurídico for orientado pelo sistema da política ou da economia, este tempo pode ser demasiado longo e causar graves problemas a outros sistemas. 
78). Em acréscimo ao risco concreto, a sociedade fez emergir o risco abstrato que passa a "ser elemento de ponderação em processos e decisões em razão de sua gravidade" (BECK, 1994, p. 78).

Na mesma linha, Carvalho (2013, p. 13) vai dizer que a sociedade como um todo se depara com uma "situação de autodestruição (self-endangered)" que é oriunda do processo de industrialização e que se materializa em riscos abstratos, invisíveis e imperceptíveis aos sujeitos expostos. Não há precedentes na história das relações sociais sobre os impactos desses novos riscos, na medida em que não se resumem a uma área geográfica e à geração presente, ou seja, são riscos transtemporais, transgeracionais e transterritoriais. Nesse cenário, a grande tarefa do Estado diante da sociedade de risco é controlar os riscos (CARVALHO, 2013, p. 13-58).

Beck (2001, p. 378) tem razão ao dizer que os riscos da tecnociência são vivenciados pela humanidade "como algo onipresente" e que, frente a essa postura, "só há três reações possíveis: negação, apatia e transformação”. Para além das evidencias tangíveis de riquezas geradas pelo desenvolvimento, como o aumento na produção de alimentos propiciada pelo uso intensivo de agrotóxicos, percebe-se que os "perigos vêm a reboque" e viajam "com o vento e a água, escondem-se por toda a parte e -, junto ao que há de mais indispensável à vida - o ar, a comida, a roupa, os objetos domésticos, atravessam todas as barreiras altamente controladas de proteção da modernidade" (BECK, 2010, p. 9). Pela sua invisibilidade, os novos riscos são importados e exportados livremente sem que o consumidor tenha ciência dos riscos que acompanham alimentos in natura, processados ou utilizados na alimentação de animais que, posteriormente, são consumidos na forma de carne e derivados.

Por tais razões, entende-se que a sociedade da segunda década do século XXI ainda não ingressou plenamente no que Beck (2008) nomina de modernização reflexiva e não reflete suficientemente sobre os riscos que ela mesma fabricou. Ainda predomina o autoconceito da sociedade industrial em que os riscos, ao mesmo tempo em que se multiplicam, também são legitimados. Estar no estágio da modernização reflexiva significa autoconfrontação e preocupação com riscos e perigos e se ocupar cada vez mais em minimizar, acautelar e gerenciar os riscos produzidos pelo desenvolvimento tecnocientífico. Para Beck (2008), não falar em riscos, "essencialmente, é um jogo de poder, isto é, especialmente verdade para a sociedade de risco mundial em que governos ou atores econômicos poderosos produzem e definem riscos para os outros”. Percebe-se, nesse ponto, que o autor fala que o Estado é omisso e conivente com a produção dos novos riscos e que não atua preventivamente para exigir dos atores econômicos segurança e responsabilidade.

Como ilustração do problema, veja-se o seguinte caso: quando a indústria bélica foi substituída pela indústria de agroquímicos, em um primeiro momento, os riscos 
foram legitimados com objetivos de ampliar a produção de alimentos para dar conta do crescimento populacional e da fome que assolava o mundo no Pós-Guerra mundial. Os danos à saúde humana não foram previstos pelos Estados que deliberadamente incentivaram a produção e a utilização de substâncias tóxicas no meio ambiente. De igual forma, no auge do desenvolvimento, demandas judiciais sobre riscos da tecnociência não eram travadas nos tribunais. A ciência, embora tardiamente, como será apresentado no próximo item, mostrou que várias doenças podem ser correlacionadas ao uso do agrotóxico glifosato, objeto do presente estudo.

Com a auto-organização de "camadas mais profundas" da sociedade, as decisões que envolvem o sistema político, econômico, jurídico e agências reguladoras nacionais e internacionais passam a ser questionadas pela sociedade. O sistema do direito é demandado a decidir, impondo o respeito aos princípios constitucionais e à regulação. Contudo, o Poder Judiciário também é obscurecido por debates e conflitos, que se originam da incerteza científica e da inércia do poder político, quando se depara com as instituições da sociedade industrial produtoras e legitimadoras "das ameaças que não conseguem controlar" (BECK, 2010, p. 67).

É preciso um choque antropológico como o que ocorreu após a catástrofe de Chernobyl para tornar "visível a invisibilidade do risco da radiação". Populações inteiras da Europa ficaram à mercê da direção dos ventos que sopravam a "nuvem de radiação", e esse fato mostrou que, nas questões existenciais da vida, a informação é essencial (BECK, 2018, p. 132). A invisibilidade de riscos, como os da radiação nuclear, mudanças climáticas, agrotóxicos, nanotecnologia, organismos geneticamente modificados, especulações financeiras e medicina reprodutiva "implica e multiplica o poder institucional da definição de risco". Na tese sustentada, Beck (2018, p. 132-133) argumenta que, "enquanto o cidadão não possuir os meios para tornar visível a ameaça invisível à sua vida, todo o poder para definir riscos globais estará nas mãos das instituições (especialistas e sistemas legais, indústria, governo etc.)". Negar a existência dos riscos, ficar cego e surdo para os efeitos colaterais e não fazer nada frente à invisibilidade natural de muitos riscos "é a estratégia mais barata, eficaz e poderosa para 'simular' a controlabilidade dos riscos." (BECK, 2018, p. 133).

Tais questões sustentam a necessidade de judicialização do risco, isto é, a necessidade de autoirritação do Direito, em suas estruturas tradicionais para assimilar, por meio da investigação, avaliação e gestão a hipercomplexidade dos novos riscos (CARVALHO, 2013, p. 13-58). Refletir sobre os riscos é despertar para a construção de um novo arranjo socioeconômico e ambiental. Assim como os riscos podem transcender as fronteiras dos estados nacionais, a autoconfrontação (reflexividade) tem potencial para estimular a sociedade a despertar para os riscos globais e envolver-se com os valores 
da preservação ambiental e da preservação da vida em todas as suas formas (BECK, 2010, p. 364).

É uma "nova maneira de gerar normas críticas na era dos riscos globais". Enquanto a sociologia padrão e os estudiosos das leis só conseguem admitir violação se houver uma norma, com os novos riscos "a violação vem antes da norma. A norma surge a partir da reflexão pública sobre o horror produzido pela vitória da modernidade”. Quando o risco é global, como no exemplo do agrotóxico, não significa dizer que é uma catástrofe global, mas sim uma previsão de catástrofe. Esse fato deveria ser suficiente para a humanidade agir e abrir um espaço moral para "uma cultura de responsabilidade que transcende velhos antagonismos e cria novas alianças, bem como novas linhas de conflito.” (BECK, 2018, p. 58-64).

Quando debates e conflitos políticos sobre os perigos da tecnociência começam a dominar as discussões nas instâncias políticas, midiáticas, científicas e de organismo da sociedade civil, a humanidade pode estar entrando no estágio que Beck (2012, p. 18) nomina de "modernização reflexiva". Os efeitos colaterais das inovações tecnocientíficas se tornam objeto de reflexão científica, política e pública. Entretanto, quando esses riscos são descodificados, surgem novos conflitos relacionados à reponsabilidade distributiva de riscos, ou seja, as negociações giram em torno da responsabilização e de como os novos riscos podem ser evitados, distribuídos, controlados e legitimados (BECK, 2012, p. 19-22).

Autoconfrontar-se com os riscos, discutir sobre eles, representa repensar as certezas da sociedade industrial que ficou cega e surda para os efeitos indesejados da industrialização quando os riscos eram compreendidos como riscos residuais e aceitáveis. Já na modernização reflexiva, as ameaças persistem, entretanto falar abertamente e discutir sobre elas passa a ser política e socialmente problemático, visto que grande parte dos países ainda se encontram na fase anterior à modernização reflexiva (BECK, 2012, p. 18-22).

O agrotóxico glifosato, produto da sociedade industrial, como se observará em sequência, é um exemplo de que a sociedade ainda não ingressou na modernização reflexiva, pois, em relação aos efeitos no meio ambiente e à saúde humana, persiste a crença de importantes segmentos da sociedade de que os riscos são efeitos colaterais suportáveis frente à necessidade de ampliar a produção de alimentos. Ingressar na modernidade reflexiva exige que os sistemas da ciência, da economia, do político e do jurídico sejam confrontados. Na fase reflexiva, a ciência se autoconfronta com a incerteza científica até suas bases para refletir com profundidade e isenção os efeitos do avanço tecnocientífico.

As decisões sobre liberação ou não do glifosato impactam no sistema econômico e no sistema socioambiental. Os sistemas político e jurídico são convocados a deliberar, 
e, frente à complexidade da problemática, as decisões devem ser amparadas em pesquisas que possam dar segurança às pessoas expostas direta ou indiretamente. Por tais razões, na sequência, a intenção é apresentar, a partir da revisão da literatura científica, como a ciência tem se posicionado sobre os riscos do agrotóxico glifosato à saúde humana.

\section{O OLHAR DA CIÊNCIA SOBRE O AGROTÓXICO GLIFOSATO}

O glifosato, $\mathrm{N}$-(phosphonomethyl) glicina, é um herbicida com uma atividade de amplo espectro introduzido para controle de ervas daninhas em áreas de produção agrícola a partir de 1974, embora sintetizado em 1964, por meio da empresa americana Monsanto (BENBROOK, 2012), adquirida em 2018 pela alemã Bayer. "O termo glifosato é utilizado para indicar tanto o ácido como seus sais, pois é reconhecido que eles são biologicamente equivalentes" (YAMADA; CASTRO, 2017).

O glifosato $\mathrm{N}$-(phosphonomethyl)glycine possui quatro sais:

a) glifosato - sal de isopropilamina (glyphosate-isopropylammonium);

b) glifosato - sal de potássio (glyphosate-potassium);

c) glifosato - sal de amônio (glyphosate-ammonium)

d) glifosato - sal de dimetilamina (glyphosate-dimetylammonium) (ANVISA, 2019b), com diferentes tipos de classificação toxicológica (ANVISA, 2018).

No Brasil, o glifosato é "formulado como sal de isopropilamina, sal de amônio, sal de potássio ou sal de trimetilsulfônico", porém a "forma mais utilizada é o sal de isopropilamina, usualmente associado ao surfactante polioxietilenoamina" (MESQUITA; RODRIGUES; MENDONÇA JÚNIOR, 2011, p. 2).

Como se trata de herbicida não seletivo, inicialmente seu uso era limitado na agricultura, porque sua aplicação se circunscrevia a determinadas épocas do ano e a intervalos entre colheita e plantio, já que eliminava todas as culturas em que era aplicado. Com a introdução das sementes tolerantes ao herbicida em 1996, seu uso foi difundido mundialmente e, em poucos anos, aumentou significativamente em diversas cultivares agrícolas (SOUMIS, 2018).

Nos Estados Unidos, entre o período de 1995 a 2014, o uso do glifosato na agricultura subiu nove vezes, e o uso agrícola global aumentou quase 15 vezes, com mais de $50 \%$ do uso em culturas resistentes a herbicidas (RH). Esse aumento foi impulsionado pela introdução de sementes geneticamente modificadas com tecnologia para eliminar a disseminação geográfica de ervas daninhas resistentes ao glifosato. Podese dizer que há certa ironia, visto que as sementes geneticamente modificadas foram desenvolvidas com objetivos de minimizar o uso de agrotóxicos (BENBROOK, 2012). 
Comercializado em mais de 119 países, o glifosato é vendido com 150 marcas diferentes. $O$ produto comercial Roundup $\AA$ é o que mais utiliza os tensoativos como polioxietileno amina (POEA) em sua formulação (BENBROOK, 2012). Nos últimos anos, o herbicida foi banido de vários países por ser considerado extremamente tóxico para o ser humano. Registra-se que sua utilização não é apenas em lavouras agrícolas, mas também em ambientes aquáticos, industriais, florestais e domésticos (MESQUITA; RODRIGUES; MENDONÇA JÚNIOR, 2011, p. 1). O herbicida também é muito utilizado em jardins e manipulado em espaços urbanos. A Agência de Proteção Ambiental dos Estados Unidos (EPA) proíbe concentrações que excedam o limite de $700 \mu \mathrm{g} / \mathrm{L}$. No Canadá, o máximo admissível de concentração é $280 \mu \mathrm{g} / \mathrm{L}$, enquanto, na Austrália, o valor-limite cai para $10 \mu \mathrm{g} / \mathrm{L}$. O glifosato, como qualquer produto químico utilizado na agricultura, pode infiltrar-se no solo e nas águas subterrâneas e águas profundas (LÄUBLI; BRAND; AESCHLIMANN, 2016).

No Brasil, segundo a Agência Nacional de Vigilância Sanitária (ANVISA, 2018), o glifosato é o ingrediente ativo mais usado nas lavouras brasileiras, alcançando, em 2017, um total de $173.150,75$ toneladas somente do ingrediente ativo, que compreende também seus sais devidamente classificados nos registros de produtos prontos para uso.

A crença inicial era de que os efeitos na saúde humana e no meio ambiente eram mínimos. Entretanto, na atualidade, a percepção sobre o glifosato, que, por muitos anos, foi caracterizado como seguro à saúde humana, passa a ser questionada por diferentes atores. $\mathrm{Na}$ medida em que estudos científicos apontam danos à saúde, decisões jurídicas suspendem seu uso ou condenam empresas a indenizações milionárias pela correlação entre o uso do glifosato com o acometimento de câncer e países começam a banir de seus territórios a sua utilização. Por tais razões, o agrotóxico glifosato está no centro de uma controvérsia entre o sistema político, econômico, jurídico e o sistema da ciência.

Assim, convém destacar que estudos científicos apontam a correlação da exposição humana ao glifosato no ambiente ocupacional, na ingestão de alimentos com resíduos do agrotóxico e na exposição ambiental com danos à saúde humana. Buscando subsídios para observar como a ciência se posiciona em relação ao herbicida, realizou-se uma pesquisa no Portal Capes com a expressão "glyphosate" que resultou em 24.568 artigos científicos avaliados por pares; na sequência, utilizaram-se as expressões "glyphosate" and "risk" sendo encontradas 7.994 publicações científicas, por fim, com as expressões "glyphosate" and "human helth", foram localizados 2.579 artigos revisados por pares.

Importa deixar claro que os resultados da pesquisa mostram que é um tema que está em discussão na ciência e que esses estudos podem aportar importantes subsídios para observar como cientistas de diversas áreas se posicionam em relação ao agrotóxico 
glifosato e se é possível verificar evidências científicas sobre potenciais riscos do agrotóxico à saúde humana. Dos 2.559 artigos foram selecionados artigos que apresentam revisões sistemáticas da literatura, visto que são textos que já realizaram uma análise ampla de publicações científicas sobre a temática do presente estudo.

Em estudo de revisão da literatura realizado por Mesquita, Rodrigues e Mendonça Júnior (2011, p. 4), a toxicidade do glifosato "se dá em função não somente da molécula química, mas também dos diluentes e aditivos incorporados ao produto comercial", o que demanda, segundo os autores, estudos mais profundos para observar a toxicidade de cada uma das formulações comerciais. Para os autores, um dos fatores que multiplica o risco de intoxicação para quem manuseia o produto é a "ampla utilização desta molécula” a nível mundial e em várias culturas em combinação com outros produtos químicos. Certamente, isso "gera necessidade de programas ligados à saúde pública, que possam atuar diretamente nos setores críticos, visando reduzir os índices de doenças e óbitos causados pelo contato com o produto" (MESQUITA; RODRIGUES; MENDONÇA JÚNIOR, 2011, p. 2-5).

No ano de 2013, foi divulgado um estudo que demonstrou que o glifosato, na concentração de partes por trilhão (ppt), induz a proliferação de células humanas de câncer de mama. Entretanto, o estudo indica que o herbicida é "menos tóxico do que outros pesticidas", mas, de acordo com os autores, este fator não diminui os "potenciais efeitos adversos à saúde para os seres humanos, pois pode ser um disruptor endócrino" (THONGPRAKAISANG et al., 2013, p. 131-135).

Séralini et al. (2014) conduziram um estudo com ratos em que as cobaias eram tratadas com água contendo o herbicida Roundup (0,1 partes por bilhão) ou com milho transgênico tolerante a Roundup. Os estudos apontaram cerca de 70 diferenças estatísticas significativas relativas a parâmetros hematológicos, químicos clínicos, químicos urinários, peso de órgãos, como coração, cérebro e fígado e modificação do peso corporal. O estudo também mostrou risco de desenvolvimento de "câncer de mama nas fêmeas, câncer e danos ao sistema gastrointestinal, rins e fígado, principalmente dos machos, além de tempo menor de vida para os animais de ambos os sexos”. Os tumores só começaram a ficar aparentes quatro meses após o início dos tratamentos (SÉRALINI et al., 2014).

Outra revisão sistemática da literatura foi realizada por Gillezeau et al. (2019) sobre níveis de exposição humana ao glifosato, incluindo a população em geral e os trabalhadores expostos ocupacionalmente. Na revisão realizada nas bases de dado da PubMed e Google Scholar, os autores encontraram 189 publicações, cinco das quais eram duplicadas. Após leitura dos resumos e palavras-chave, 139 estudos foram excluídos por não tratarem do objetivo do estudo, restando 45 artigos para revisão do texto completo que, em novo refinamento e em conformidade com o objetivo proposto, 
foram excluídos mais 26 estudos, visto que as pesquisas eram "realizadas in vitro e não incluírem dados sobre seres humanos", bem como por terem o foco apenas na "detecção no ambiente e não em humanos ou foram editoriais ou artigos de revisão sem dados originais", restando assim 19 estudos para análise (GILLEZEAU et al., 2019, online).

Dos 19 estudos restantes da revisão realizada por Gillezeau et al. (2019), cinco tratavam de pesquisas sobre a exposição ocupacional ao glifosato, onze sobre a exposição da população e três relataram a exposição tanto de trabalhadores como da população em geral. É importante registrar que, na metodologia adotada, a análise dos resultados foi realizada somando as cinco pesquisas com trabalhadores expostos acrescentada das três pesquisas que foram realizadas tanto com trabalhadores como com a população, resultado em oito pesquisas para esse grupo de análise. O segundo grupo de análise foi representado pelos onze estudos realizados especificamente com a população, somandose também os três estudos que abrangiam ambos, resultado em 14 estudos científicos (população mais trabalhadores expostos). Nos oito estudos que relatavam a exposição ao glifosato no ambiente ocupacional, foram relatados níveis urinários em 423 trabalhadores expostos ocupacionalmente. Por sua vez, os 14 estudos (população mais trabalhadores expostos) relataram terem encontrado em 3.298 indivíduos níveis de glifosato em vários biofluídos. Os "níveis urinários médios em indivíduos ocupacionalmente expostos variaram de 0,26 a 73,5 $\mu \mathrm{g} / 1$; os níveis urinários da exposição ambiental variaram de 0,16 a 7,6 g/l” (GILLEZEAU et al., 2019, online).

Da revisão sistemática realizada por Gillezeau et al. (2019, online), "dois estudos mediram as tendências temporais na exposição", e, nestes dois estudos, foram identificadas "proporções crescentes de indivíduos com níveis detectáveis de glifosato na urina ao longo do tempo". Também foram encontrados resíduos de glifosato "em poeira dentro de residências não agrícola", o que sugere que a "exposição não é apenas ocupacional" (GILLEZEAU et al., 2019, online).

Em outra investigação sobre possível associação entre exposição alta e cumulativa ao glifosato e o risco de linfoma não Hodgkin (NHL) em seres humanos, Zhang et al. (2019) realizaram uma meta-análise sobre estudos realizados em animais e com seres humanos relacionados ao linfoma com a inclusão da recente pesquisa realizada pela Agricultural Health Study (AHS) no ano de 2018. Os autores concluíram que a metaanálise realizada sugere uma ligação convincente entre exposição ao glifosato e aumento do risco de NHL (ZHANG et al., 2019).

Em síntese, a análise dos artigos de revisão mostrou que os pilares que sustentam a liberação de agrotóxicos são abalados pela antecipação global de perigos atuais e futuros, que vão emergindo conforme a ciência evolui e tem mais voz. O desenvolvimento de pesquisas independentes por laboratórios de pesquisa de Universidades e as respectivas publicações de resultados em periódicos científicos, 
validados por pares, são provas contundentes de que há riscos no uso do agrotóxico glifosato.

Pesquisas como as relatadas apontam que o glifosato pode ser associado com algumas doenças, razão pela qual, nos últimos anos, o potencial toxicológico do glifosato tem sido revisado e debatido por vários órgãos normativos e por autoridades em diversas partes do mundo. Na sequência, buscar-se-á apresentar como as principais agências de regulação internacional e a ANVISA estão tratando da divergência científica em relação aos indicativos de riscos do glifosato.

\section{A CONTROVÉRSIA CIENTÍFICA ENTRE OS ORGANISMOS INTERNACIONAIS E DAS AGÊNCIAS REGULADORAS SOBRE O GLIFOSATO}

Em 2015, a Organização Mundial da Saúde (OMS) refez estudos sobre diversos agrotóxicos, entre eles o glifosato, e o classificou como "provavelmente carcinogênico para os seres humanos”. A OMS realizou uma revisão da literatura científica sobre pesquisas que encontraram resíduos de glifosato no solo e na água com indicação de toxicidade para macro e microrganismos, efeitos sobre a composições microbianas e potenciais efeitos indiretos na saúde humana, animal e vegetal (BENBROOK, 2012).

A International Agency for Research on Cancer (IARC) também classificou o glifosato como provavelmente carcinogênico para os seres humanos (grupo 2A). O IARC concluiu “que há 'fortes evidências' de que a exposição ao glifosato é genotóxico por meio de pelo menos dois mecanismos conhecidos por estarem associados a carcinógenos humanos (dano de DNA, estresse oxidativo)" (VAN BRUGGEN et al., 2018, online).

O que embasou o parecer do IARC foi a realização de uma pesquisa em março de 2015, que reuniu um grupo de trabalho com a participação de 17 especialistas de 11 países durante sete dias. Esses pesquisadores realizaram uma revisão ampla da literatura, em bases científicas internacionais, sobre evidências científicas do potencial de carcinogenicidade de cinco inseticidas e herbicidas organofosforados, entre eles o glifosato, classificando-o como "provavelmente carcinogênico para humanos". Nas bases científicas utilizadas pelo IARC, o resultado apresentado relatava evidências consideradas "limitadas" para câncer em humanos em exposições reais e evidências "suficientes" de câncer em animais experimentais submetidos ao glifosato "puro" (WHO, 2016).

Em sentido contrário, em 15 de março de 2017, o Comitê de Avaliação dos Riscos (Committee for Risk Assessment - RAC) da European Chemicals Agency (ECHA, 2016), concluiu que "as evidências científicas disponíveis não atendiam aos critérios 
para classificar o glifosato como carcinogênico, mutagênico ou tóxico para a reprodução", entretanto apontaram que pode causar "dano ocular 1; H318 (provocar lesões oculares graves) e danos à vida aquática 2; H411 (tóxico para a vida aquática com efeitos duradouros)" (ECHA, 2016, online).

Além do estudo da RAC, Benbrook (2012, online) registra que a Environmental Protection Agency (EPA) dos EUA após realização de pesquisas considerou o glifosato como "não susceptível de ser carcinogênico para os seres humanos". O autor observa três razões para as conclusões opostas apresentadas pelo EPA e pelo IARC sobre a genotoxicidade do glifosato: i] utilização de diferentes bases de dados para as conclusões dos dois organismos: o EPA usou como base "estudos regulatórios comissionados, não publicados", em que os resultados das pesquisas apresentavam que 99\% foi negativo para a correlação glifosato e câncer; enquanto o IARC se baseou, principalmente, em estudos científicos revisados por pares e publicados nas principais bases científicas internacionais, "dos quais 70\% eram positivos, ou seja, de 118 artigos científicos analisados, 83 artigos correlacionavam o glifosato com o câncer em humanos”. ii] utilização de diferentes metodologias de pesquisa: "a avaliação da EPA baseou-se em grande parte nos dados de estudos sobre o glifosato técnico, enquanto a revisão do IARC colocou importância nos resultados dos ensaios formulados de GBH e AMPA"; iii] diferentes objetos de estudo: na avaliação do EPA só foram consideradas "exposições alimentares típicas da população em geral, assumindo usos legais de culturas alimentares" e não foram consideradas, portanto, não foram abordadas "exposições e riscos ocupacionais geralmente mais altos". Por seu lado, o IARC em sua avaliação "abrangeu dados de cenários típicos de exposição dietética e ocupacional”. São duas conclusões distintas com base em estudos diferentes, o que impõe a necessidade de ampliar a "investigação sobre as exposições do mundo real aos produtos químicos no âmbito de GBHs formulados e o destino biológico e as consequências de tais exposições" (BENBROOK, 2012, online).

As pesquisas do IARC desencadearam reação imediata e negativa dos produtores agrícolas, que acusaram o Instituto de não ter realizado estudos de forma adequada e que as conclusões eram em grande parte contraditórias com a investigação publicada pelo EPA (TORRETTA et al., 2018).

O mais dramático é que as consequências dos riscos globais são incalculáveis, pois, como se observou, organismos internacionais têm visões diferentes sobre a segurança do mesmo produto. Quando lançados no mercado, estavam alicerçados no sonho de segurança da primeira modernidade que foi calcada na utopia científica de que acidentes acontecem e podem ser compensáveis (BECK, 2010). O problema é que, se a parte da ciência que comprova ter dados suficientes sobre os danos do glifosato à 
saúde das presentes e futuras gerações estiver com a razão, os riscos presentes no agrotóxico são incompensáveis pela ameaça que representam para a humanidade.

Entretanto, autoridades públicas e representantes populares, "impossibilitados de um exame detalhado e multidisciplinar, acabam abrindo o caminho para a consagração dos experts que monopolizam a atuação das instâncias tecnocientíficas passando a ser o centro de decisão" (CARVALHO; BAHIA, 2019, p. 9). O sistema do direito, frente à complexidade dos riscos invisíveis, abstratos, transgeracionais e transterritoriais dos agrotóxicos, sente-se "intimidado pela crescente complexidade das questões", contudo a ele é exigido manter uma contínua inter-relação com o sistema da ciência frente à exigência de decisões cada vez mais científica do Direito (CARVALHO; BAHIA, 2019, p. 9). Por isso, deve-se desconfiar de discursos que não se sustentam em bases científicas.

Veja-se ainda que, em maio de 2018, a Autoridade Europeia para a Segurança dos Alimentos (EFSA, 2019, online) publicou os resultados de uma extensa revisão por pares realizada por peritos de Estados-Membros da União Europeia. Os peritos observaram os teores de resíduos de glifosato e compararam os dados encontrados com os limites máximos de resíduos (LMR) de pesticidas no interior e na superfície dos gêneros alimentícios e dos alimentos para animais, de origem vegetal ou animal, como previstos no art. 12 do Regulamento n. 396/2005 da Autoridade Europeia para Segurança dos Alimentos. Ao final da revisão da literatura, os peritos de EstadosMembros da União Europeia compararam os valores de exposição calculados com os valores de referência toxicológica para o glifosato e seus metabólitos previstos no "Relatório da EFSA de 2015, no Regulamento da EU n. 1141/2010 da Comissão, alterado pelo Regulamento de Execução (UE) n. 380/2013 da Comissão no âmbito da avaliação do impacto do glifosato e dos seus resíduos nos alimentos para animais e na saúde animal”. Nessa pesquisa, não foram analisados dados toxicológicos e o parecer também não aborda o perfil toxicológico do glifosato e seus metabólitos. Como conclusão o relatório indicou resíduos em inúmeros alimentos utilizados por animais e alimentos voltados para o consumo humano acima dos níveis permitidos (EFSA, 2019, online). Relembre-se, aqui, que os animais são alimentados com grãos, ração e pasto expostos a agrotóxicos e parte da alimentação humana é composta de alimentos derivados de origem animal.

A licença do glifosato na União Europeia expira em 15 de dezembro de 2022. O procedimento de reavaliação deve iniciar em dezembro de 2019, três anos antes da data de expiração. Entretanto, os preparativos iniciaram em março de 2019, quando a UE anunciou a criação de um grupo de relatores de Estados-Membros formado pela França, Hungria, Países Baixos e Suécia que serão responsáveis pela avaliação do dossiê sobre o glifosato e, ao final, pela elaboração do relatório preliminar de avaliação que será submetido e analisado pela European Food Safety Authority (EFSA, 2010) em 2021. 
Registra-se que a EFSA é responsável na UE pela avaliação de risco de substâncias químicas e por pedidos de renovação da homologação de substâncias ativas. A EFSA trabalha em estreita colaboração com peritos científicos dos Estados-Membros que realizam uma revisão por pares para homologar ou não a renovação de substâncias ativas.

Mais ainda, em julho de 2019, em decisão inédita na União Europeia, o Parlamento austríaco proibiu o uso de glifosato com o argumento de que "'a evidência científica do efeito carcinogênico do veneno de plantas está aumentando" e que é de responsabilidade do parlamento "banir este veneno de nosso meio ambiente". A proibição está em discordância com as diretivas da UE que, em princípio, mantém a licença do princípio ativo até 2022 (PARLAMENTO..., 2020, online).

Além da iniciativa da Áustria de proibir o uso de glifosato em seu território, o Tribunal Administrativo francês de Lyon proibiu em janeiro de 2019 a comercialização do herbicida Roundup 360, revertendo a autorização de comercialização com a utilização do princípio da "precaução". Com argumentos semelhantes ao da Áustria, o Tribunal francês se posicionou no sentido de indicar que o "glifosato pode ser cancerígeno para humanos e prejudicial para a reprodução da vida humana e aquática, apesar da aprovação do bloco europeu do ativo químico”. (RINKE; MARTIN, 2019, online).

Veja-se, ainda, que, em 10 de abril de 2019, citando como argumento a "toxicidade" de produtos que contêm o princípio ativo glifosato e seu impacto no meio ambiente e na saúde, o Ministério da Agricultura e Desenvolvimento Rural do Vietnã ordenou a retirada do herbicida da lista de produtos autorizados no país (RINKE; MARTIN, 2019).

No Brasil, em 2018, a ANVISA (2018), por demanda do Ministério Público, fez uma reavaliação do ingrediente ativo glifosato concluindo que ele está em conformidade com Lei 7.802/89 e que o "o Glifosato não apresenta características mutagênicas, teratogênicas e carcinogênicas, bem como não é desregulador endócrino e não é tóxico para a reprodução". Em 26 de fevereiro de 2019, a ANVISA (2019a) aprovou a realização da Consulta Pública no 613/2019 - Reavaliação Toxicológia do Glifosato, entre 08 de março de 2019 a 08 julho de 2019, prorrogada por mais 30 dias, como parte da reavaliação do glifosato que prevê sua manutenção no mercado brasileiro.

A Consulta Pública realizada pela ANVISA (2019b) recebeu 4.602 respostas via internet. A primeira questão inquiriu se o respondente era a favor da manutenção do uso de glifosato no Brasil e com o estabelecimento de restrições para o seu uso. Do total de respostas, apenas 18,39\% eram favoráveis a manutenção do agrotóxico no Brasil. Como a consulta permitia mais de uma escolha, há mais contribuições nas respostas à questão formulada do que o total de fichas preenchidas e não preenchidas. As respostas 
aos itens da Consulta Pública somaram 11.239, sendo que, em favor da manutenção do herbicida, foram contabilizados 2.131 votos (18,96\%) e contra contabilizou-se 9.108 (81,03\%). Em relação ao texto em discussão na Consulta Pública (Nota Técnica no 23/2018/SEI/CREAV /GEMAR/GGTOX/DIRE3/ da ANVISA de 2018), do total de 4.602 participantes da pesquisa, $26,47 \%$ respondeu que concordam com texto em discussão e 41,59 que discordam integralmente. Observa-se que apenas 10,93\% do público participante discorda da necessidade de regulamentação para o glifosato (ANVISA, 2019b). Tem-se, aqui, que, em que pese à infindável discussão acerca da validade de consultas públicas, a população respondente manifestou-se no sentido de que o glifosato não deve ser mantido no Brasil. Resta saber a importância do posicionamento da sociedade civil na consulta pública sobre o tema.

Em síntese, observou-se que há de fato uma controvérsia científica em relação aos riscos do glifosato à saúde humana. Enquanto alguns organismos internacionais e nacionais de regulação de produtos atestam a segurança do agrotóxico, com argumentos também baseados em pesquisas científicas, que indicam que o glifosato, se usado em concordância com as medidas sanitárias e o correto manejo do produto durante a aplicação, não causa problemas à saúde do trabalhador no seu ambiente laboral. De igual forma, atestam que o consumidor quando exposto a resíduos nos alimentos ou na água que consome não é afetado em sua saúde com resquícios do produto. Entretanto, como observado, diferentes organismos internacionais de regulação se posicionaram que o glifosato causa danos à saúde humana, também amparado em estudos científicos. A isso se deve agregar que vários países já baniram o agrotóxico de seus territórios utilizando dados científicos para a tomada de decisão.

Em uma realidade de controvérsia científica como a que foi descrita, na sequência, serão examinadas ações do sistema jurídico em que são exigidas respostas sobre os ruídos dos efeitos colaterais na saúde humana de decisões do sistema político e do sistema econômico de liberar o agrotóxico glifosato. Os danos do herbicida estão chegando aos tribunais, e o sistema jurídico é convocado a decidir e como ele está decidindo é que se buscará evidenciar com a análise de casos concretos da Corte Americana e de tribunais brasileiros.

\section{DECISÕES DO SISTEMA JURÍDICO DOS ESTADOS UNIDOS E DO BRASIL FRENTE AOS RISCOS DO AGROTÓXICO À SAÚDE HUMANA}

Como observado por Beck (2008, 2010, 2012, 2018), é na sociedade de risco que as ameaças produzidas pela industrialização e os avanços tecnocientíficos começam a tomar corpo e a impactar nos ecossistemas e na saúde humana. Dar-se conta de que existem riscos invisíveis, intangíveis e irreversíveis exigem reflexão e autoconfrontação 
com o sistema econômico e político. Nesse cenário, o direito é convocado a decidir e a "delimitar o grau de tolerabilidade destes riscos" e quais são os riscos aceitáveis e que são possíveis da humanidade e dos ecossistemas suportarem. Importante ter presente que não cabe ao direito "eliminar os riscos, nem trazer segurança, mas sim vislumbrando os mais variados aspectos possíveis, a partir da visão de todos os ramos do saber que tem envolvimento com a problemática" incumbe ao direito "estabelecer as normas para o gerenciamento destes riscos, definindo quais as atividades que, apesar de portarem riscos ambientais, podem ser admitidas pela sociedade ou não" (WOLTMANN; SOUTO; CAMPOS, 2013, p. 98-101).

Como exemplo de controvérsia sobre os danos do glifosato à saúde humana e o posicionamento do sistema judicial diante das lacunas deixadas pelas legislações, na sequência, será apresentado decisão da Corte Americana que condenou em primeira instância a empresa produtora de glifosato Monsanto ao pagamento de uma indenização de US\$ 289 milhões.

Está-se diante da demanda de Dewayne Johnson, no Processo CGC-16-550128, nos EUA, propôs na Courte da Superior Court of California - County of San Francisco ação contra a Monsanto Company. O caso é conhecido como "Dewayne Johnson VS. Monsanto Company et al.” alegando Responsabilidade Estrita (Defeito de projeto, falha em avisar), Negligência, Violação de Garantia Implícita e Danos Punitivos. O processo em sua exordial relata que, em "1970, a Defendants Monsanto Company, Inc. descobriu as propriedades herbicidas do glifosato e passou a comercializá-lo sob a marca Roundup", sendo que esse produto é não seletivo, o que significa que elimina todas as ervas daninhas em que é aplicado, razão pela qual tem grande aceitação entre os agricultores. Em "2001 o glifosato havia se tornado o ingrediente ativo mais utilizado na América com 85-90 milhões de libras usadas anualmente. Esse número cresceu para 185 milhões libras em 2007. A partir de 2013, o glifosato foi o herbicida mais utilizado no mundo" (SUPERIOR COURT OF CALIFORNIA, 2016). Até março de 2019, tramitam, só nos Estados Unidos, aproximadamente 42.000 ações contra a Monsanto/Bayer alegando doenças relacionadas à exposição ao glifosato (MONSANTO, 2019).

Nos autos do Processo da Corte Americana, há o relato de que a multinacional de biotecnologia agrícola é a maior empresa produtora de glifosato do mundo. A partir de 2009, a empresa passou a responder por $27 \%$ das sementes do mercado mundial, a maioria da marca Roundup Ready® que apresentam a vantagem da resistência ao Glifosato, permitindo ao agricultor a capacidade de controlar as ervas daninhas, pois o produto pode ser pulverizado nas lavouras durante a fase de crescimento sem prejudicar a colheita. Estima-se que " $70 \%$ do milho e algodão, e $90 \%$ dos campos de soja nos Estados Unidos eram Roundup Ready®”. (SUPERIOR COURT OF CALIFORNIA, 2016, online). 
A Superior Court Of California (2016, online) traz como provas inúmeros estudos que confirmam que resíduos de glifosato são encontrados em "rios, riachos e lençóis freáticos em áreas agrícolas onde o Roundup ${ }^{\circledR}$ é usado. Foi encontrado na comida, na urina de trabalhadores agrícolas e, até mesmo, na urina de moradores urbanos que não estão em contato direto com o glifosato."

Para mostrar o potencial lesivo do produto, anexam o resultado da pesquisa realizada em março de 2015 pela International Agency for Research on Cancer (IARC), pela agência World Health Organization (WHO) que, apoiada em revisão de inúmeros estudos de exposição ao glifosato em humanos em vários países do mundo, elaboraram quadro demonstrativo com as principais implicações do uso deste produto desde 2001 (SUPERIOR COURT OF CALIFORNIA, 2016). Como já registrado, em julho de 2015, o IARC publicou formalmente a monografia sobre o Glifosato classificando-o como pertencente ao Grupo 2a, o que significa ser provavelmente carcinogênico para humanos, concluindo que os "cânceres mais associados à exposição ao glifosato são o Linfoma non-Hodgkin e outros tipos de hematopoiese cânceres, incluindo linfoma linfocítico/leucemia linfocítica crônica, linfoma de células B e mielotna múltipla.” (WHO, 2016, online). Em relação à controvérsia entre os resultados do IARC e a EPA, a defesa de Dewayne Johnson traz que a própria EPA em duas ocasiões "descobriu que os laboratórios contratados pela Monsanto para testar toxicidade de seus produtos Roundup ${ }^{\circledR}$ para fins de registro cometeu fraude." (SUPERIOR COURT OF CALIFORNIA, 2016, online).

Em sua contestação, a empresa Monsanto é sucinta na defesa, alegando em frases curtas que nega todas as acusações, citando a falta de provas científicas confiáveis sobre o perigo ou defeito do produto, acusando o autor da ação negligente no uso, visto que os rótulos do glifosato possuíam todas as informações "no estado da ciência e tecnologia do conhecimento" atual. O pedido foi julgado procedente, e a Monsanto foi condenada pelo Tribunal americano a pagar um total de U\$289.253.209,32 dólares para a vítima a título de danos punitivos, perdas econômicas passadas, perdas econômicas futuras e perdas não econômicas futuras (SUPERIOR COURT OF CALIFORNIA, 2016).

No dia 24 de junho de 2020, a Bayer anunciou que vai direcionar mais de 10 bilhões de dólares para firmar acordo buscando solucionar o litígio nas cortes americanas de 95 mil processos relacionados ao herbicida Roundup e sua associação com câncer e outras doenças. Mesmo prestes a firmar o acordo bilionário, reservando mais de 1 bilhão de dólares para demandas que ainda estão em andamento nos Estados Unidos, a Bayer defende a segurança do glifosato (BAYER, 2020).

Outros casos, como o de Ronald Peterson and Jeff Hall v. Monsanto na St. Louis Circuit Court - Missouri; Pilliod, et al. v. Monsanto et al., na Alameda County Superior 
Court - California; Gordon v. Monsanto na St. Louis County - Missouri, seguem a mesma de linha de acusação.

No Brasil, o Ministério Público Federal ajuizou, em 2014, a Ação Civil Pública n. 0021371-49.2014.4.013400 contra a União e a ANVISA objetivando que: i] a ANVISA seja compelida a "reavaliar a toxicidade de 8 (oito) ingredientes ativos publicados na Resolução ANVISA RDC no 10/2008” dentre os quais o glifosato; ii] seja determinado à União que suspenda "os registros de produtos que tenham como princípio ativo as substâncias mencionadas, até que seja realizada a reavaliação, pela ANVISA, sobre a sua toxicidade, em razão de indícios de que elas poderiam ser nocivas à saúde humana e ao meio ambiente”. Na mesma ACP, foi solicitada a antecipação dos efeitos da tutela para que a ANVISA realize a reavaliação toxicológica de vários ingredientes ativos de pesticidas, entre eles o glifosato dentro do "prazo de 180 (cento e oitenta) dias ou outro prazo razoável a ser fixado pelo juízo" (BRASIL, 2014).

Na Ação Civil Pública n. 0021371-49.2014.4.013400 impetrada, o MPF requereu o ingresso no pleito das empresas FMC Química do Brasil Ltda.; Monsanto do Brasil Ltda; Nortox S/A; Cheminova Brasil Ltda.; Syngenta Proteção de Cultivos Ltda.; Taminco do Brasil Produtos Químicos Ltda; Sindicato Nacional da Indústria de Produtos para Defesa Vegetal (Sindiveg); Associação Brasileira dos Produtores de Soja e, no polo passivo, o Instituto Brasileiro do Meio Ambiente e dos Recursos Naturais Renováveis. Insta registrar que o Sindiveg e a FMC Química do Brasil Ltda. já tinham solicitado para serem admitidos como assistentes litisconsorciais logo após a ACP ajuizada pelo MPF (DISTRITO FEDERAL, 2018).

No dia 23 de abril de 2014, o Juiz Federal José Márcio da Silveira e Silva da 7a Vara/SJ-DF denegou a solicitação de antecipação de tutela, admitindo ainda o ingresso do Sindiveg e da FMC Química do Brasil Ltda. como assistentes litisconsorciais das rés. Em sua decisão, o magistrado indica que, para "a concessão da antecipação dos efeitos da tutela faz-se necessária a presença da verossimilhança, suportada pela prova inequívoca do direito alegado, além do fundado receio de dano irreparável ou de difícil reparação". Observa ainda que "nenhum dos requisitos se configura, apesar do zelo demonstrado pelo MPF ao tratar de matéria tão sensível” (DISTRITO FEDERAL, 2014, online). O MPF, inconformado, reiterou pedido de antecipação de tutela com base em fatos supervenientes à propositura da ação, reforçando a solicitação de que não sejam "concedidos novos registros de produtos que contenham quaisquer dos ingredientes ativos objeto desta ação”. Em 22 de junho de 2015, a Juíza Federal substituta Luciana Raquel Tolentino de Moura, da 7a Vara da Seção Judiciária do Distrito Federal, em sua decisão, entende que ainda é prematuro interromper a concessão de novos registros, "devido à ausência efetiva de certeza técnico-científica, decorrente das reavaliações ainda não finalizadas e do impacto considerável para a agricultura do país”. Concedeu 
parcialmente a antecipação dos efeitos da tutela "apenas para determinar à Anvisa que finalize os processos de reavaliação toxicológica dos ingredientes ativos" (DISTRITO FEDERAL, 2015, online).

Em 03 de agosto de 2018, a Juíza Federal substituta Luciana Raquel Tolentino de Moura, da 7a Vara da Seção Judiciária do Distrito Federal, concedeu a antecipação dos efeitos da tutela para que a "União não conceda novos registros de produtos que contenham como ingredientes ativos abamectina, glifosato e tiram”, bem como decidiu pela suspensão, no prazo de 30 dias, do "registro de todos os produtos que utilizam destas substâncias até que a ANVISA conclua os procedimentos de reavaliação toxicológica", exigindo ainda que a ANVISA dê prioridade para a "reavaliação toxicológica de abamectina, glifosato e tiram, os quais devem ser concluídos até 31/12/2018” (DISTRITO FEDERAL, 2018, online).

A Advocacia-Geral da União (AGU) entrou com recurso contra a decisão da Juíza Luciana Raquel Tolentino de Moura, fundamentando o pedido na grave lesão à ordem pública e à economia pública em torno de três pontos: i] "da impossibilidade de o Judiciário intervir em questões técnicas acerca do registro e (re)avaliação de agrotóxicos no país", o que seria, no entendimento da AGU, uma grave violação à ordem administrativa; ii] "dos drásticos impactos da decisão proferida considerando as especificidades de cada ingrediente ativo", com impactos à balança comercial brasileira, risco de desabastecimento interno e quebra de produtividade e competitividade no mercado externo"; iii] do flagrante opção pela medida mais gravosa sem análise quanto ao custo benefício (AGU, 2018, online). Em sequência, no dia 23 de agosto de 2018, o Desembargador Kássio Nunes Marques do Tribunal Regional Federal da Primeira Região (TRF-1) cassou a decisão da Juíza e acatou o recurso da AGU fundamentando que a proximidade do plantio a suspensão acarretaria "grave risco de lesão à ordem econômica" (PONTES, 2018, online).

Essa posição mostra que os danos à saúde humana e ao meio ambiente são considerados danos colaterais. O conflito ambiental, nas palavras de Beck (2018, p. 88), “não está ocorrendo no 'ambiente' propriamente dito, mas em instituições, partidos políticos, sindicatos e corporações globais”. Por outro lado, as demandas ao sistema judiciário e a resposta do sistema da ciência mostram que, ao refletirem sobre os riscos, as decisões sobre a evolução da tecnologia não estão mais restritas ao setor político e "o cérebro da sociedade não pode ser mais localizado" (BECK, 2010, p. 67). Observou-se que, nos Estados Unidos, as decisões judiciais resultam no acolhimento da demanda e na condenação de executivos em reparações milionárias em casos que o Tribunal aceitou a correlação entre o dano à saúde e o uso do herbicida glifosato, "demonstrando que a evolução da ciência e da tecnologia não ocorrem independente da sociedade" (HOHENDORFF; JOTZ; MACHADO, 2017, p. 111). 
Importa referir que os riscos do glifosato viajam livremente nos produtos importados e exportados. O consumidor final, o trabalhador rural que aplica no campo e o trabalhador urbano que manipula alimentos com agrotóxicos, bem como o empregado de empresas produtoras são vítimas desprotegidas de substâncias que podem causar sérios danos à saúde e aos ecossistemas. A exposição ao produto é um fato, e há evidências científicas que constituem prova incontestável de dano. É obrigação do Estado proteger a saúde humana e o meio ambiente.

Em relação a qualidade do ambiente laboral rural, registra-se recente Ação Civil Pública Cível - ACPCiv 0000680-48.2019.5.23.0003 do Ministério Público do Trabalho - Procuradoria Regional do Trabalho da 23a Região, portanto, na seara do Direito do Trabalho, de 15 de agosto de 2019, em que o Autor é o Ministério Público da União e o Ministério Público do Estado de Mato Grosso e figuram como Réus a Associação dos Produtores de Soja e Milho do Estado de Mato Grosso; Federação da agricultura e Pecuária do Estado de Mato Grosso (BRASIL, 2019). O objetivo da ação impetrada busca "impor à coletividade de produtores rurais, no Estado de Mato Grosso, a obrigação de abster-se de utilizar agrotóxicos que contenham o princípio ativo glifosato em seu processo produtivo, com a finalidade de proteger a saúde e vida dos trabalhadores rurais do Estado”, ou seja, busca-se a preservação do meio ambiente laboral do trabalhador rural mediante a

imposição, a todos os produtores rurais do Estado que empreguem trabalhadores, do dever de não utilizar agrotóxicos que contenham glifosato, satisfazendo, com isso, a situação jurídica ativa, titularizada pela coletividade de trabalhadores, de ter seu ambiente de trabalho livre de substâncias que violem seu direito à saúde e à vida (BRASIL, 2019, online).

Nesse ponto, é importante trazer o estudo realizado por Bohner, Araújo e Nishijima (2013, p. 339) com trinta trabalhadores rurais do município de Chapecó, estado de Santa Catarina, sobre o que significa agrotóxicos, destaca-se que, para 76,7\% dos trabalhadores, os agrotóxicos representam ser veneno e 3,3\% "associam-no a um remédio para as plantas”. À medida que a pesquisa avançada impressiona que, dos 30 trabalhadores rurais, apenas $23,3 \%$ dos trabalhadores rurais "costumam ler sempre o receituário agronômico e 30\% compreendem todas as informações contidas na bula dos agrotóxicos". Entretanto, apenas "36,7\% revelam compreender totalmente as tarjas, e 20\% entendem todos os desenhos presentes nos rótulos dos agrotóxicos" (BOHNER; ARAÚJO; NISHIJIMA, 2013, p. 339).

Por tais razões, assume importância o art. 225 da Constituição Federal que expressa literalmente que o direito à sadia qualidade de vida é um direito humano fundamental e um valor indisponível da sociedade brasileira. Também não se pode esquecer de que especificamente em relação aos agrotóxicos, os riscos podem converter- 
se em danos irreparáveis à saúde humana, e a pessoa exposta tem o direito de exigir responsabilização e mitigação de riscos quando sua saúde é violada. Além disso, o sistema do direito e o sistema político, pela lente do dano ambiental futuro, têm o dever de construir novas formas de regulação baseadas no reconhecimento da complexidade sistêmica da vida e do meio ambiente, devendo organizar e gerir respostas jurídicas para que os seres humanos expostos a agrotóxicos tenham seu direito à sadia qualidade de vida garantido. Confirmado o risco, as vítimas têm o direito de serem indenizadas pelos danos à saúde e ao meio ambiente.

\section{CONCLUSÃO}

Os aportes teóricos de Beck mostram que o ponto decisivo é sair da certeza calcada na segurança, que é assegurada pelos produtores de agrotóxicos, para poder avançar e refletir como a ciência comunica os resultados de investigações científicas sobre produtos que representam riscos à saúde humana e ao meio ambiente. A sociedade, ao tornar-se reflexiva, certamente, irá questionar firmemente a dinâmica e a estrutura da produção dos riscos e perigos do desenvolvimento tecnocientífico. Como observado, nas Cortes americanas e brasileiras, o exemplo do glifosato começa a aflorar via sistema jurídico e a exigir compensação às vítimas.

As provas do sistema da ciência proporcionam realidade à sociedade de risco, razão pela qual a informação fornecida pela ciência, pela mídia e por outras instituições sociais auxiliam no processo social de autoconfrontação da sociedade com os riscos que ela própria criou ao lançar produtos, como o glifosato, sem pesquisas suficientes para indicar sua utilização segura.

No fundo, as descobertas científicas levaram a sociedade a movimentos que vão desde a proibição do agrotóxico gliflosato em alguns países (Suécia, Vietnam, Bermudas, Sky Lanka), reavaliação em outros (França, Austrália, UE) e sanções jurídicas, como a busca de reparação por meio do sistema jurídico. Resultados científicos diferentes são utilizados para embasar demandas que chegam ao sistema jurídico, tanto pelo lado que defende as empresas fabricantes do glifosato (pesquisas que não encontraram nas análises realizadas potencial cancerígeno) como pelos dados científicos que pautam a linha de acusação e conseguem demonstrar nexo causal entre o uso de glifosato e a doença relacionada na demanda.

A gestão dos riscos dos agrotóxicos é complexa e situa-se na fronteira das decisões do sistema político e do sistema econômico, que se centram no crescimento econômico com a ampliação da produção de alimentos e ampliação do PIB nacional. De tudo o que foi dito, tornam-se emergentes as questões transcientíficas. Ao sistema da ciência, ao sistema político e ao sistema do direito é solicitado que caminhem juntos em busca de 
uma gestão coletiva dos riscos dos agrotóxicos. Responder e desvendar um problema em um contexto de incerteza científica também é um momento privilegiado para incentivar o diálogo entre os sistemas. A controvérsia em relação ao glifosato, alimentada pela indecibilidade social de seus riscos, reforça a necessidade de ampliar pesquisas com seres humanos expostos ao agrotóxico.

Não é ignorando, negando ou subestimando a existência de riscos que se avançará. Razão pela qual a presente pesquisa, ao examinar dados do sistema da ciência (pesquisas científicas), do sistema político (agências nacionais e internacionais de regulação) e do sistema do direito (ações e decisões na esfera judicial), objetivou participar de alguma forma do que Beck nomina de reflexividade (autoconfrontação) sobre os riscos.

\section{REFERENCIAS}

ADVOCACIA GERAL DA UNIÃO (AGU). Procuradoria Regional da União da 1a Região. Suspensão de Liminar ou Antecipação de Tutela. Processo n.102431750.2018.4.01.0000. Data: 22 de agosto de 2018. Disponível em: http://pje2g.trf1.jus.br:80/pje-web/Processo/ConsultaDocumento/listView.seam?x=18 082220040371100000003324909 Númerododocumento: 8082220040371100000003 324909. Acesso em: 27 jan. 2021.

AGÊNCIA NACIONAL DE VIGILÂNCIA SANITÁRIA (ANVISA). 2018. Processo $\mathrm{n}^{\circ}$ 25351.056754/2013-17. Nota Técnica no 23/2018/SEI/CREAV /GEMAR/GGTOX/DIRE3/ ANVISA. 2018. Disponível em: http://portal.anvisa.gov.br/documents/111215/117833/Nota+t\%C3\%A9cnica+23+de +2018+-+Glifosato/faac89d6-d8b6-4d8c-8460-90889819aaf7 . Acesso em: 25 out. 2020.

AGÊNCIA NACIONAL DE VIGILÂNCIA SANITÁRIA (ANVISA). Consultas Públicas. 2019a. Disponível em: http://portal.anvisa.gov.br/consultas-publicas\#/ Acesso em: 25 out. 2020.

AGÊNCIA NACIONAL DE VIGILÂNCIA SANITÁRIA (ANVISA). Consulta Pública $\mathrm{n}^{\circ}$ 613/2019 - Reavaliação Toxicológia do Glifosato. 2019b. Disponível em: http://formsus.datasus.gov.br/site/resultado.php?id_aplicacao=45725. Acesso em: 25 out. 2020.

BAYER faz acordo de $\mathrm{R} \$ 53$ bilhões para encerrar processos envolvendo glifosato. Deutsche Welle, 24 jun. 2020. Disponível em: https://www.dw.com/pt-br/bayer-fazacordo-de-r-53-bilh\%C3\%B5es-para-encerrar-processos-envolvendo-glifosato/a-53932736. Acesso em: 25 out. 2020. 
BECK, Ulrich. D'une théorie critique de la société vers la théorie d'une autocritique sociale. 3. ed. Paris: Deviance and Society, 1994. v. 18.

BECK, Ulrich. La politique dans la société du risque. Revue du MAUSS, n. 17, p.376392, 2001. DOI: 10.3917/rdm.017.0376. Disponível em: https://www.cairn.info/revuedu-mauss-2001-1-page-376.htm\#s1n13. Acesso em: 25 out. 2020.

BECK, Ulrich. Momento cosmopolita” da sociedade de risco. Tradução: Germana Barata e Rodrigo Cunha. Revista Eletrônica de Jornalismo Científico, 10 dez. 2008. Disponível em: http://www.comciencia.br/comciencia/handler.php?section=8\&edicao $=41 \&$ id $=501$. Acesso em: 25 out. 2020 .

BECK, Ulrich. Sociedade de Risco: rumo a uma nova outra modernidade. São Paulo: Editora 34, 2010.

BECK, Ulrich. A reinvenção da política: rumo a uma teoria da modernização reflexiva. In: BECK, Ulrich; GIDDENS, Anthony; LASCH, Scott. Modernização reflexiva: política, tradição e estética na ordem social moderna. Trad. de Magda Lopes. 2. ed. São Paulo: Edunesp, 2012.

BECK, Ulrich. A Metamorfose do Mundo: novos conceitos para uma nova realidade. Tradução de Maria Luiza X. de A. Borges. Rio de Janeiro: Zahar, 2018.

BENBROOK, Charles M. Impacts of genetically engineered crops on pesticide use in the U.S. - the first sixteen years. Environmental Sciences Europe, 2012. Disponível em: https://enveurope.springeropen.com/articles/10.1186/2190-4715-24-24. Acesso em: 25 out. 2020.

BOHNER, Tanny Oliveira Lima; ARAÚJO, Luiz Ernani Bonesso; NISHIJIMA, Toshio. O Impacto Ambiental do uso de Agrotóxicos no Meio Ambiente e na Saúde dos Trabalhadores Rurais. Revista Eletrônica do Curso de Direito da UFSM, v. 8, p. 329 . 341, 2013. Disponível em: https://periodicos.ufsm.br/revistadireito/article/view/8280 /4993. Acesso em: 25 out. 2020.

BRASIL. Tribunal Regional do Trabalho da 23a Região. Ação Civil Pública Cível ACPCiv 0000680-48.2019.5.23.0003. Autor: Ministerio Publico Da Uniao e Ministério Público Estado Mt. Data da autuação: 15 out. 2019.

CARVALHO, Délton Winter. Dano Ambiental Futuro: a responsabilização civil pelo risco ambiental. 2. ed. Porto Alegre: Livraria do Advogado, 2013.

CARVALHO, Ester de; BAHIA, Carolina Medeiros. A nanotecnologia e seus riscos desconhecidos: reflexões acerca da necessidade de um novo pensar sobre o Direito. Revista Eletrônica do Curso de Direito da UFSM, Santa Maria, v. 14, n. 2, p. 1-31, 
2019. DOI: 10.5902/1981369430985. Disponível em: https://periodicos.ufsm.br/revistadireito/article/view/30985/pdf Acesso em: 25 out. 2020.

DISTRITO FEDERAL. Tribunal Regional Federal da Primeira Região. 7a Vara Federal. Processo $\mathrm{N}^{\circ}$ 0021371-49.2014.4.01.3400. Relator Juíz Federal em auxílio José Márcio da Silveira e Silva. Data do julgamento: 23 abr. 2014. Disponível em: https://processual.trf1.jus.br/consultaProcessual/processo.php?proc $=00213714920144$ 013400\& secao=DF\&pg=1\&enviar=Pesquisar. Acesso em: 27 jan. 2021.

DISTRITO FEDERAL. Tribunal Regional Federal da Primeira Região. 7 ${ }^{\text {a }}$ Vara Federal. Processo $\mathrm{N}^{\circ}$ 0021371-49.2014.4.01.3400. Relatora Juíza Federal Substituta Luciana Raquel Tolentino de Moura. Data do julgamento: 22 jun. 2015. Disponível em: https://agroemdia.com.br/wp-content/uploads/2018/08/Decisa\%CC\%83oproibic\%CC\%A7a\%CC\%83o-reg-Glifosatoe-outros-2.pdf . Acesso em: 25 out. 2020.

DISTRITO FEDERAL. Seção Judiciária do Distrito Federal. Decisão $\mathbf{n}^{\circ} 0021371$ 49.2014.4.01.3400. Juíza Federal Substituta Luciana Raquel Tolentino de Moura. Data do Julgamento: 03 ago. 2018. Disponível em: https://agroemdia.com.br/wpcontent/uploads/2018/08/Decisa\%CC\%83o-proibic\%CC\%A7a\%CC\%83o-regGlifosatoe-outros-2.pdf. Acesso em: 25 out. 2020.

EUROPEAN CHEMICALS AGENCY (ECHA). Committee for Risk Assessment. Glyphosate not classified as a carcinogen by ECHA. Helsinki, 2016. Disponivel em: https://echa.europa.eu/-/glyphosate-not-classified-as-a-carcinogen-by-echa. Acesso em: 25 out. 2020.

EUROPEAN FOOD SAFETY AUTHORITY. Glyphosate. IARC International Agency for Researchon Cancer Lyon, 2019. Disponivel em: https://www.efsa.europa.eu/en/topics/topic/glyphosate. Acesso em: 25 out. 2020.

GILLEZEAU, Christina et al. The evidence of human exposure to glyphosate: a review. Environ Health, v. 18, n. 2, jan. 2019. Disponível em: https://www.ncbi.nlm.nih.gov/pmc/articles/PMC6322310/. Acesso em: 25 out. 2020.

GREGORI, Pedro. México proíbe herbicida Glifosato e outros países do continente limitam seu uso. Publica - Agência de Jornalismo Investigativo, 28 jan. 2021. Disponivel em: https://apublica.org/2021/01/mexico-proibe-herbicida-glifosato-eoutros-paises-do-continente-limitam-seu-uso/\#: :text=De\%20acordo\%20com\%20levan tamento\%20da,que\%20proibiram\%20totalmente\%20o\%20herbicida. Acesso em: 28 jan. 2021.

HOHENDORFF, Raquel; JOTZ, Eleonora; MACHADO, Cristine. As nanotecnologias e o meio ambiente: alternativa jurídica fundada na bioética e nos princípios éticos, legais 
e sociais (ELSA). In: HUPFFER, Haide Maria; ENGELMANN, Wilson. BioNanoÉtica: Perspectivas Jurídicas. São Leopoldo: Trajetos Editorial, 2017.

LÄUBLI, Markus; BRAND, Bastian; AESCHLIMANN, Andrea. Glyphosate and AMPA in drinking water. Metrohm International Headquarters, Herisau, Switzerland, 2016. Disponível em: https://theanalyticalscientist.com/fileadmin/tas/issues/App_No tes/122-0016-metrohm-Whitepaper-Glyphosate-in_drinking-water.pdf. Acesso em: 25 out. 2020.

LUHMANN, Niklas. La sociedad de la sociedad. México: Herder, 2007.

MESQUITA, Hélida Campos de; RODRIGUES, Ana Paula Medeiros dos Santos; MENDONÇA JÚNIOR, Antonio Francisco de. Riscos toxicológicos do herbicida glyphosate. Agropecuária Centífica do Semi-árido. v. 7, n. 2, p. 1 - 5, abr./jun. 2011. Disponível em: http://revistas.ufcg.edu.br/acsa/index.php/ACSA/article/download/1 30/pdf. Acesso em: 25 out. 2020.

MONSANTO: Roundup substantial factor in man's cancer, jury finds in key verdict. The Guardian, 19 Mar. 2019. Disponivel em: https://www.theguardian.com/business/2019/mar/19/monsanto-trial-roundup-verdictedwin-hardeman-cancer. Acesso em: 25 out. 2020.

MORAES, P. V. D.; ROSSI, P. Comportamento ambiental do glifosato. Scientia Agraria Paranaensis, v. 9, n. 3, p. 22-35, 2010. Disponível em: https://www.cevs.rs.gov.br/upload/arquivos/201712/06131757-comportamentoambiental-do-glifosato.pdf . Acesso em: 28 jan. 2021.

PARLAMENTO da Áustria aprova banir o glifosato. Deutsche Welle. Disponível em: https://www.dw.com/pt-br/parlamento-da-\%C3\%A1ustria-aprova-banir-o-glifosato/a49448256. Acesso em: 25 out. 2020.

RINKE; Andreas; MARTIN, Michelle. Germany to ban use of glyphosate from end of 2023. Reuters, 2019. Disponível em: https://uk.reuters.com/article/usgermany-glyphosate/germany-to-ban-use-of-glyphosate-from-end-of-2023-idUK KCN1VP0TY. Acesso em: 25 out. 2020.

SÉRALINI, Gilles-Eric et al. Republished study: long-term toxicity of a Roundup herbicide and a Roundup-tolerantgenetically modified maize. Environmental Sciences Europe, v. 26, n. 14, jan. 2014. Disponível em: https://enveurope.springeropen.com/articles/10.1186/s12302-014-0014-5. Acesso em: 25 out. 2020.

SOUMIS, Nicolas. Glyphosate: the world's most widely used herbicide. Quebec: Primer, 2018. 
SUPERIOR COURT OF CALIFORNIA (SCC). County of San Francisco. Case Number: CGC16550128. Dewayne Johnson Vs. Monsanto Company et al. 2016. Disponível em: https://webapps.sftc.org/ci/CaseInfo.dll?CaseNum=CGC16550128\&S essionID=F262FE06DEDFB2614D54BC8A4ACA18ABC0A96D6D. Acesso em: 25 out. 2020.

THONGPRAKAISANG, Siriporn et al. Glyphosate induces human breast cancer cells growth via estrogen receptors. Food and Chemical Toxicology, v. 59, p. 129-136, 2013. Disponível em: https://www.sciencedirect.com/science/article/pii/S02786915130036 33/pdfft? md5=147a247c027130ec0997128bbe7234c4\& pid=1-s2.0-0278691513003633main.pdf. Acesso em: 25 out. 2020.

TORRETTA, Vincenzo et al. Critical Review of the Effects of Glyphosate Exposure to the Environment and Humans through the Food Supply Chain. Sustainability, Jan. 2018. Disponível em: https://www.mdpi.com/2071-1050/10/4/950. Acesso em: 25 out. 2020.

VAN BRUGGEN, A. H. C. et al. Environmental and health effects of the herbicide glyphosate. Science of The Total Environment, v. 616/617, p. 255-268, Mar. 2018. Disponível em: https://www.sciencedirect.com/science/article/pii/S004896971733027 9. Acesso em: 25 out. 2020.

WOLTMANN, Angelita; SOUTO, Raquel Buzatti; CAMPOS, Maiara Cristina Schneider. (Re)Pensando o Direito diante da Sociedade de Risco: considerações sobre a emergência da mudança do paradigma ambiental na América Latina. Revista Eletrônica do Curso de Direito da UFSM, v. 8, p. 94-106, 2013. Disponível em: https://periodicos.ufsm.br/revistadireito/article/view/8251/4972. Acesso em: 25 out. 2020.

WORLD HEALTH ORGANIZATION (WHO). IARC International Agency for Researchon Cancer. Monograph on Glyphosate. IARC International Agency for Researchon Cancer Lyon, 2016. Disponível em: https://www.iarc.fr/wpcontent/uploads/2018/11/QA_Glyphosate.pdf. Acesso em: 25 out. 2020.

YAMADA, Tsuioshi; CASTRO, Paulo Roberto de Camargo e. Efeitos do glifosato nas plantas: implicações fisiológicas e agronômicas implicações fisiológicas e agronômicas. Informações Agronômicas - International Plant Nutrition Institute, n. 119, set. 2007. Disponível em: https://www.stopogm.net/sites/stopogm.net/files/webfm/plataforma/ EfeitosGlifosatoPlantasImplica\%C3\%A7\%C3\%B5es.pdf Acesso em: 25 out. 2020.

ZHANG, L. et al. Exposure to glyphosate-based herbicides and risk for non-Hodgkin lymphoma: A meta-analysis and supporting evidence. Mutat Res. v. 781, p.186-206, jul./set. 2019. Disponível em: https://www.ncbi.nlm.nih.gov/pubmed/31342895. Acesso em: 25 out. 2020. 


\section{NOTA}

Declaramos que o artigo intitulado "OS RISCOS DO AGROTÓXICO GLIFOSATO: CONTROVÉRSIA CIENTÍFICA OU NEGAÇÃO DO DANO À SAÚDE HUMANA?, submetido à Revista Opinião Jurídica, representa fruto direto das pesquisas desenvolvidas pelos autores e das relações interinstitucionais produzidas no âmbito do projeto de investigação científica: "Agrotóxicos e Sociedade de Risco: Limites e Responsabilidade pelo Risco Ambiental" que tem apoio da Fundação de Amparo à Pesquisa do Estado do Rio Grande do Sul (FAPERGS), tendo os autores realizado, concomitantemente, as tarefas de seu planejamento, execução e revisão da seguinte forma: 1) Jeferson Jeldoci Pol: desenvolveu de forma mais específica a parte relativa sobre o olhar da ciência sobre o agrotóxico glifosato com a técnica "revisão sistemática da literatura" e participou das análises da controvérsia científica entre os organismos internacionais e das agências reguladoras sobre o agrotóxico glifosato; 2) Haide Maria Hupffer: desenvolveu de forma mais específica a análise das decisões do sistema jurídico dos Estados Unidos e do Brasil frente aos riscos do agrotóxico à saúde humana, participando também da análise da controvérsia cientifica entre os organismos internacionais e das agências reguladoras sobre o agrotóxico glifosato; 3) Joao Alcione Sganderla Figueiredo: desenvolveu de forma mais específica a parte relativa à reflexão sobre a sociedade de risco e a necessária autoconfrontação com os riscos da tecnociência pela lente de Ulrich Beck.

Por ser verdade, firmamos a presente declaração em Novo Hamburgo e São Leopoldo, em 29 de janeiro de 2021.

\section{Como citar este documento:}

POL, Jeferson Jeldoci; HUPFFER, Haide Maria; FIGUEIREDO, João Alcione Sganderla. Os riscos do agrotóxico glifosato: controvérsia científica ou negação do dano à saúde humana?. Revista Opinião Jurídica, Fortaleza, v. 19, n. 32, p. 267-295, set./dez. 2021. 